\title{
SISTEM REGISTRASI ONLINE PENERIMAAN SISWA BARU DI MASA PANDEMI COVID-19
}

\author{
Doddy Ferdian Nasution ${ }^{1}$ \\ 1 Universitas Nusa Mandiri \\ Email:114002346@nusamandiri.ac.id
}

\begin{abstract}
Abstrak
Perkembangan teknologi di era 4.0 membuat segala aspek ikut berkembang, sehingga menuntut manusia untuk bisa memanfaatkannya dengan bijak. Pendidikan merupakan salah satu bidang yang terkena dampak tersebut. Adanya virus Covid-19 yang masuk ke Indonesia di akhir tahun 2019, pola hidup masyarakat menjadi berubah, termasuk di bidang Pendidikan. Kebijakan pemerintah yang menghimbau masyarakat untuk melakukan kegiatan dari rumah mengharuskan kita untuk melakukannya dengan teknologi yang ada saat ini. Dalam kegiatan belajar mengajar, pihak sekolah dituntut untuk memaksimalkan fasilitas e-learning. Selain itu, kondisi ini juga berdampak bagi siswa dan pihak sekolah dalam penerimaan siswa baru. Banyak sekolah yang terdampak akibat pandemi virus Covid-19. Pihak sekolah mengupayakan untuk tidak melakukan penerimaan siswa baru secara offline. Kondisi ini membuat pihak sekolah harus membuat sistem baru untuk keperluan tersebut. Penerimaan siswa baru secara offline juga dirasa tidak efektif dan tidak akurat karena sering terjadi redudansi dalam pengolahan data. Dari permasalahan yang dihadapi, kami merancang sistem registrasi online penerimaan siswa baru berbasis website dengan metode RAD. Bahasa pemrograman yang digunakan yaitu PHP dan Mysql. Dengan adanya sistem tersebut diharapkan dapat memudahkan calon siswa dan pihak sekolah untuk penerimaan siswa baru. Selain itu website ini juga akan memudahkan guru dan pihak tata usaha untuk lebih efektif dan efisien dalam mengelola data siswa dan data pembayaran sehingga meminimalisir terjadinya redudansi data.
\end{abstract}

Kata kunci: Sistem, Registrasi, Siswa Baru, Website

\begin{abstract}
The development of technology in the 4.0 era has made all aspects develop, so that it demands humans to be able to use it wisely. Education is one of the areas affected by this. With the Covid-19 virus that entered Indonesia at the end of 2019, people's lifestyles have changed, including in the field of education. Government policies that urge people to carry out activities from home require us to do it with current technology. In teaching and learning activities, schools are required to maximize e-learning facilities. In addition, this condition also has an impact on students and the school in admitting new students. Many schools have been affected by the Covid-19 virus pandemic. The school is trying not to accept new students offline. This condition makes the school have to create a new system for this purpose. Admission of new students offline is also deemed ineffective and inaccurate because of frequent redundancies in data processing. From the problems faced, we designed a website-based online registration system for new student admissions using the RAD method. The programming languages used are PHP and Mysql. With this system, it is hoped that it can make it easier for prospective students and the school to accept new students. In addition, this website will also make it easier for teachers and administrators to be more effective and efficient in managing student data and payment data so as to minimize the occurrence of data redundancies.
\end{abstract}

Keywords: System, Registration, New Students, Website

\section{PENDAHULUAN}

Perkembangan teknologi di era 4.0 membuat segala aspek ikut berkembang sehingga menuntut manusia untuk bisa memanfaatkannya dengan bijak. Teknologi informasi memegang peranan dalam mengubah penyelesaian suatu pekerjaan untuk meningkatkan efisien kerja serta meningkatkan kreatifitas dan aktivitas pegawai yang memiliki bakat dan kemampuan yang bagus (Putra \& Shadiq, 2020). Adanya perkembangan teknologi informasi memiliki dampak positif yang luar biasa, salah satunya dibidang pendidikan yang dituntut untuk meningkatkan kualitas mutu Pendidikan, membuat pekerjaan lebih efektif http://ejournal.bsi.ac.id/ejurnal/index.php/ijse 
dan efisien termasuk dalam hal proses belajar mengajar dan administrasi sekolah (Prabowo \& Agustina, 2017). Hal tersebut akan mampu diwujudkan dengan cara memanfaatkan teknologi informasi sebagai alat penunjang pendidikan yang diharapkan dapat memberikan dampak serta solusi yang baik dalam dunia Pendidikan.

Adanya virus Covid-19 yang masuk ke Indonesia di akhir taun 2019 juga berdampak pada pola hidup masyarakat, termasuk bidang pendidikan. Kebijakan pemerintah yang menghimbau masyarakat untuk melakukan kegiatan beribadah, bekerja dan belajar dari rumah mengharuskan kita untuk melakukannya dengan teknologi yang ada saat ini. Dalam kegiatan belajar mengajar pun pihak sekolah dituntut untuk memaksimalkan fasilitas e-learning. Tak hanya berdampak pada kegiatan belajar mengajar saja, namun kondisi ini juga berdampak bagi siswa dan pihak sekolah dalam penerimaan siswa baru. Dengan adanya perkembangan teknologi informasi, proses penerimaan siswa baru secara online dapat dilakukan oleh setiap sekolah dengan memanfaatkan web dan internet untuk membantu proses pengolahan data secara akurat dan cepat (Sarwindah, 2018)

Dalam kegiatan pembelajaran, beberapa sekolah telah mengupayakan untuk melakukan proses belajar secara daring dengan memanfaatkan fasilitas group chat, virtual meeting, dan fasilitas lainnya. Sebagai upaya meminimalisir penyebaran virus Covid-19, pihak sekolah juga mengupayakan untuk tidak melakukan penerimaan siswa baru secara offline. Kondisi ini membuat pihak sekolah harus membuat sistem baru untuk keperluan tersebut. Selain itu, penerimaan siswa baru secara offline juga dirasa tidak efektif dan tidak akurat karena sering terjadi redudansi dalam pengolahan data.

Dari permasalahan diatas, kami merancang sistem registrasi online siswa untuk penerimaan siswa baru. Sistem ini dibangun dengan metode pengembangan perangkat lunak Rapid Application Development $(R A D)$, dengan memanfaatkan teknologi website sehingga registrasi bisa dilakukan dari mana saja.

Sistem tersebut diharapkan dapat memudahkan calon siswa dan pihak sekolah untuk melakukan proses registrasi penerimaan siswa baru secara online. Sistem penerimaan siswa baru berbasis web juga diharapkan dapat mendukung himbauan pemerintah untuk melakukan social distancing demi meminimalisir penyebaran virus Covid-19. Selain itu, website ini diharapkan juga akan memudahkan guru dan pihak tata usaha dalam mengelola data siswa dan data administrasi pendaftaran secara lebih efektif dan efisien sehingga meminimalisir terjadinya redudansi data. Novelty dari penelitian ini yaitu system yang di rancang menggunakan metode $R A D$, dimana metode tersebut belum banyak digunakan dalam studi kasus serupa

\section{METODE PENELITIAN}

\subsection{Metode Pengumpulan Data}

Pada tahap ini, dilakukan pengumpulan data yang akan digunakan untuk membangun sistem. Tahap yang dilakukan yaitu dengan cara observasi terhadap beberapa website sekolahan kemudian di dukung dengan studi Pustaka yang terkait dengan penelitian.

a. Metode Observasi

Pada metode ini, penulis melakukan observasi secara langsung dengan cara mengamati beberapa website penerimaan siswa baru. Output yang diperoleh yaitu penulis mendapatkan gambaran mengenai website yang akan dibangun.

b. Studi Pustaka

Penulis mengumpulkan data dari berbagai studi literatur, baik berupa jurnal, buku, prociding dan sumber lain yang berhubungan dengan sistem yang akan dibangun.

\subsection{Metode Pengembangan Sistem}

Rapid Application Development (RAD) merupakan model pengembangan perangkat lunak secara sequential linear dengan siklus waktu yang digunakan untuk pengembangan sangat pendek (Bolung \& Tampangela, 2017). Oleh karena itu, jika kita memahami dengan betul kebutuhan sebuah sistem, maka tidak akan dibutuhkan waktu yang lama untuk membangun sebuah sistem. Berikut adalah aktifitas pemodelan RAD: 


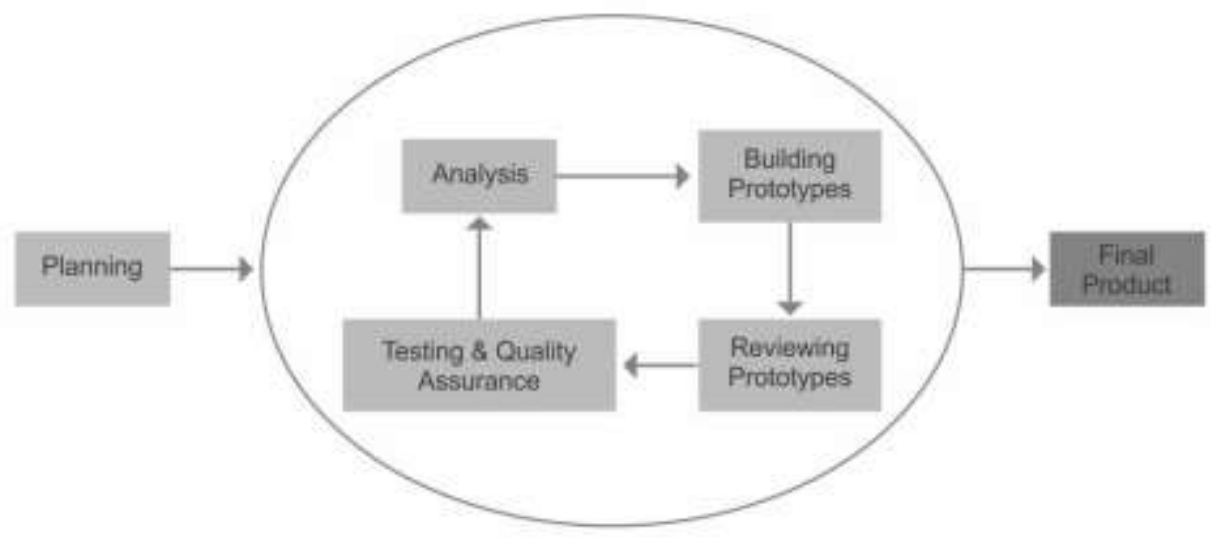

Gambar 1. Model RAD (Rapid Application Development)

Sumber : (Bolung \& Tampangela, 2017)

a. Bussiness Modelling

Pada tahapan ini akan dilakukan identifikasi kebutuhan informasi dari sebuah sistem, biasanya dilakukan dengan merumuskan pertanyaan-pertanyaan terkait informasi yang akan mengendalikan proses bisnis, informasi yang akan dihasilkan dan siapa yang menggunakannya.

b. Data Modelling

Pada tahapan ini informasi yang sudah didefinisikan di tahap pemodelan bisnis kemudian disaring ulang ke dalam objek-objek data yang digunakan untuk bisnis. Atribut dari masing masing objek data diindentifikasi kemudian dicari hubungan antar objek satu dengan objek lainnya.

c. Process Modelling

Pada tahapan ini, aliran informasi yang sudah didefinisikan di tahap pemodelan data kemudian ditransformasikan untuk menciptakan aliran informasi yang dibutuhkan sebuah bisnis guna mendapatkan kembali objek data.

d. Application Generation

Pada tahapan ini perangkat lunak mulai dibangun dengan pemrograman. RAD lebih banyak melakukan proses sistem kerja dari kompenen yang sudah ada ataupun membangun komponen-komponen program yang dapat digunakan lagi. Pada taha ini digunakan alat bantu untuk membangun perangkat lunak.

e. Testing and Turnover

Proses RAD lebih ditekankan pada pemakaian ulang komponen program. Oleh karena itu, komponen yang sudah ada telah diuji, sehingga lebih efisien waktu dalam pengujian. Tetapi, terhadap komponen yang baru harus diuji secara keseluruhan

\section{HASIL DAN PEMBAHASAN}

\subsection{Bussiness Modelling}

Pada tahap ini dilakukan Analisa mengenai system yang ada di sekolah. Siswa melakukan pendaftaran secara offline atau langsung datang ke sekolah. Sedangkan dalam kondisi Covid-19, hal itu tidak bisa dilakukan karena adanya aturan social distancing. Dari permasalahan di atas, dibuatkan system pendaftaran secara online melalui website. Calon siswa mendaftar melalui website dengan membuat akun kemudian mengisikan data diri. Data calon siswa yang telah masuk kemudian diproses oleh Guru dan bagian Tata Usaha akan disimpan untuk dipantau kedepannya. 
Indonesian Journal on Software Engineering (IJSE)

Vol. 7, No. 1, Juni 2021, hlm. 69-77

\subsection{Data Modelling}

Data modelling yang dibuat seperti di bawah ini.

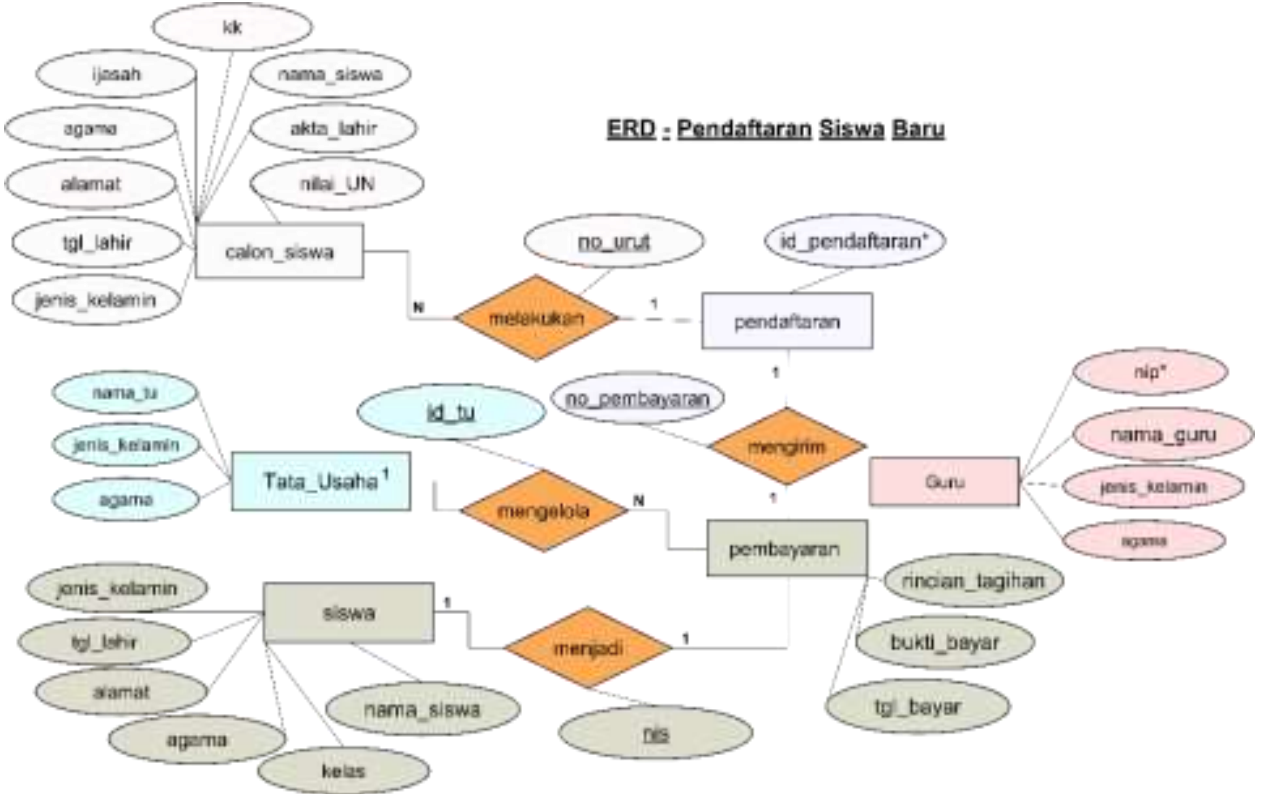

Gambar 2. ERD (Entity Relationship Diagram)

Pada gambar 2. Diatas merupakan ERD yang digunakan untuk memodelkan bisnis, terdapat beberapa entitas yang masing-masing entitas memiliki beberapa atribut dan setiap entitas memiliki hubungan dengan entitas lainnya sesuai dengan kebutuhan sistem.

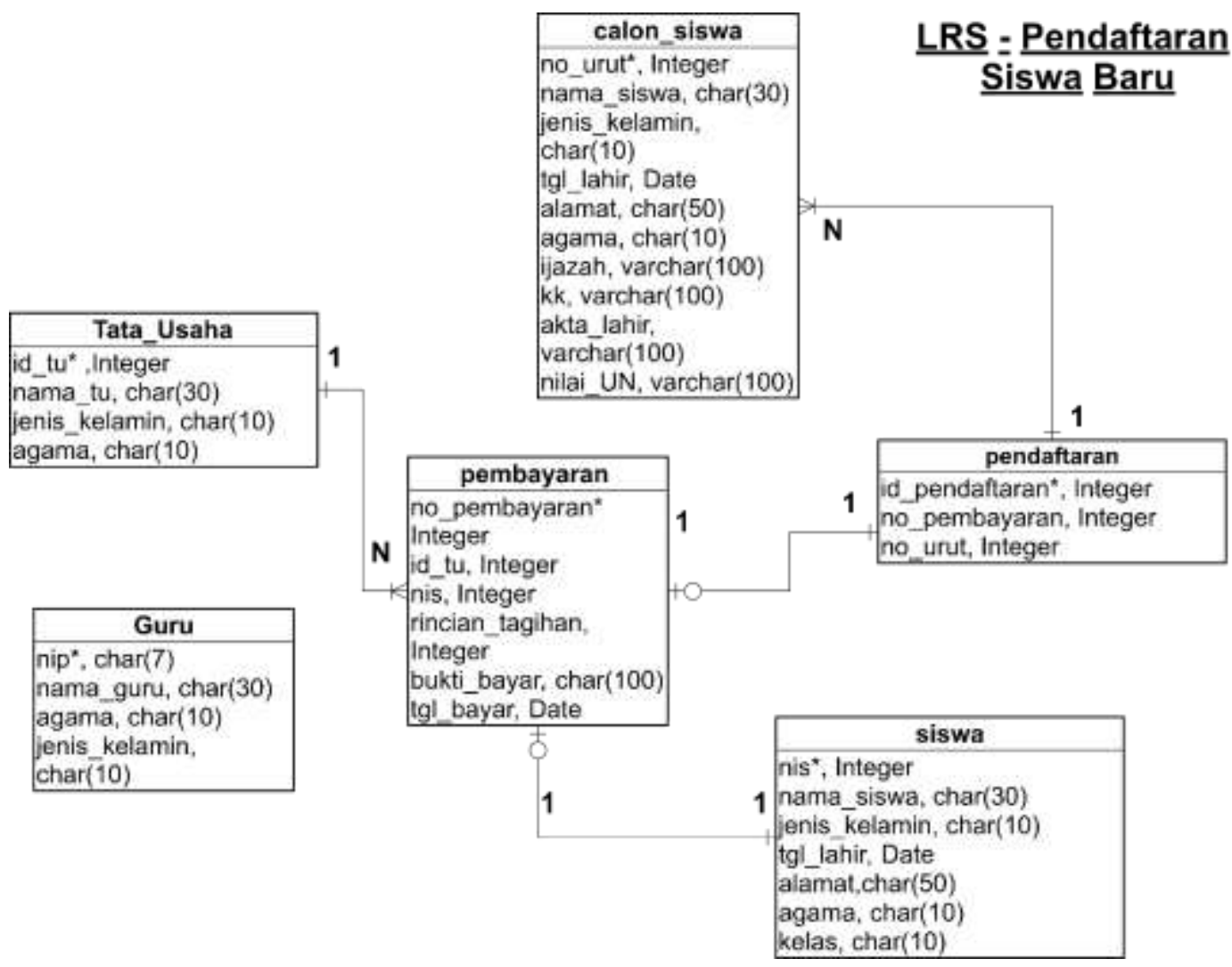

Gambar 3. Desain database sistem Registrasi Online 
Indonesian Journal on Software Engineering (IJSE)

Vol. 7, No. 1, Juni 2021, hlm. 69-77

p-ISSN: 2461-0690

Akreditasi KEMENRISTEKDIKTI, No. 85/M/KPT/2020

e-ISSN: 2714-9935

Pada gambar 3. terdapat 6 tabel yang digunakan untuk keperluan sistem registrasi online penerimaan siswa baru. Setelah menggambarkan ERD selanjutnya digambarkan kedalam Logical Record Structure (LRS) Ke enam tabel tersebut memiliki kardinalitas masing-masing yang berelasi dengan tabel lainnya.

\subsection{Process Modelling}

Desain sistem yang dibuat adalah perancangan sistem Registrasi online penerimaan siswa baru berbasis web. Setiap aktivitas pengguna pada sistem akan tercatat pada system database. Berikut adalah alur sistem yang diusulkan:

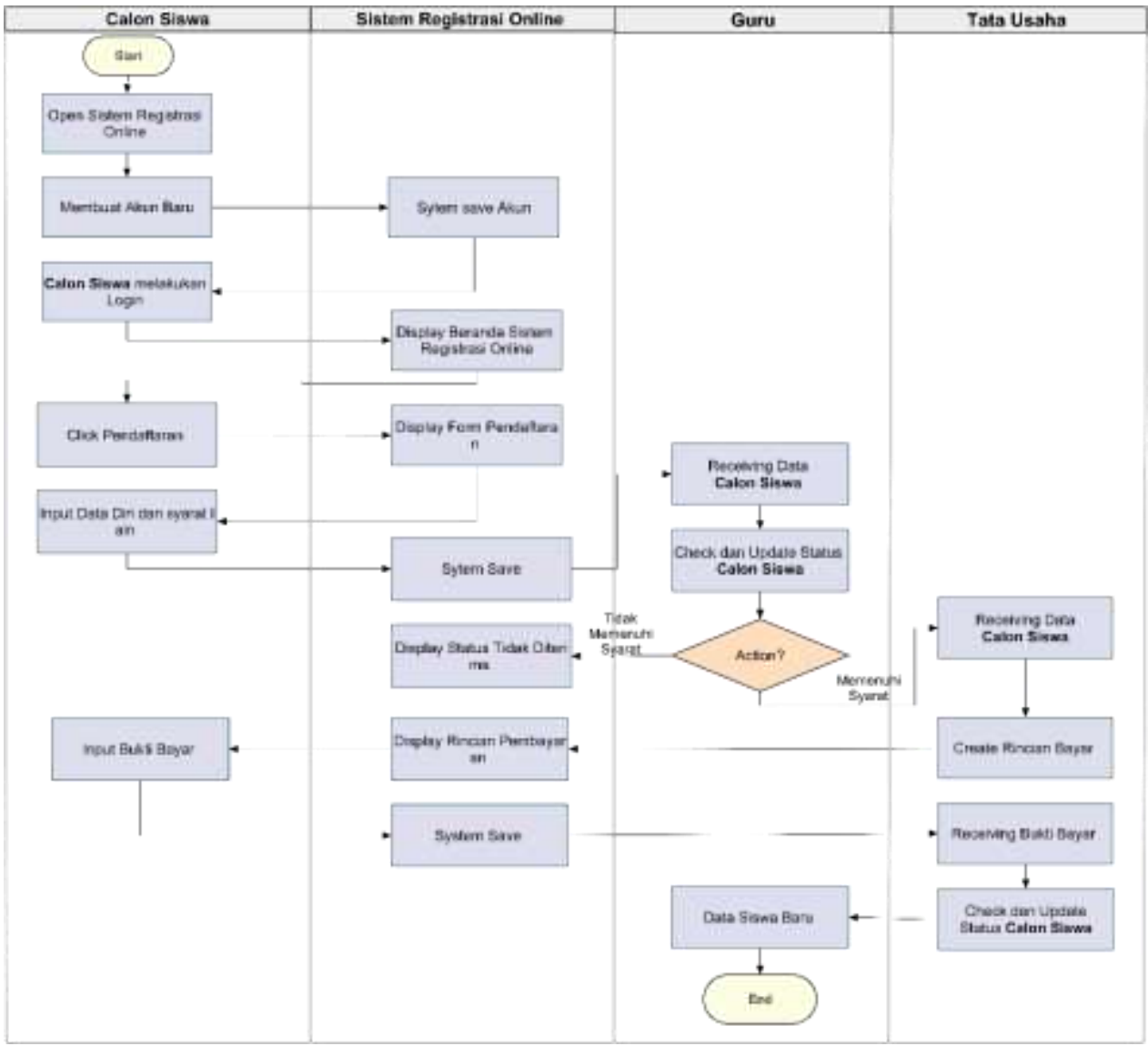

Gambar 4. Alur Sistem Registrasi Online

Pada gambar 4 dijelaskan bahwa sistem registrasi online untuk penerimaan siswa baru pada smp $\mathrm{XYZ}$ dimulai dengan siswa membuka portal registrasi online kemudian membuat akun untuk melakukan pendaftaran, siswa meng-klik menu pendaftaran yang nanti akan muncul form pendaftaran. Kemudian siswa melakukan input data diri beserta dengan upload syarat yang lainnya seperti ljazah, Kartu Keluarga dan Akta Kelahiran. Setelah itu data pendaftar akan tersimpan dalam database kemudian pihak guru melakukan filter data yang memenuhi syarat dan yang tidak memenuhi syarat, jika tidak memenuhi syarat maka akan muncul status tidak diterima, jika memenuhi syarat maka data pendaftar akan diterima oleh pihak Tata Usaha kemudian dibuatkan rincian pembayaran. Setelah itu, pendaftar melakukan proses pembayaran dan upload bukti bayar ke sistem registrasi online. Setelah itu, bukti bayar diterima oleh pihak Tata Usaha kemudian diolah dan dipastikan kembali kebenaran data yang masuk. Selanjutnya data diserahkan kepada pihak guru dan guru menerima data siswa baru. 
Indonesian Journal on Software Engineering (IJSE)

Vol. 7, No. 1, Juni 2021, hlm. 69-77

\subsection{Application Modelling}

Sistem Registrasi online penerimaan siswa baru ini dibuat berdasarkan komponen-komponen penting dari sistem yang telah dianalisis dan didesain dengan teknologi berbasis web, dengan Bahasa pemrograman PHP dan MySQL. Proses penerapan sistem Registrasi Online ini dibutuhkan tools yaitu web browser seperti Google Chrome, Mozilla Firefox, atau browser sejenis lainnya. Pengujian yang dilakukan dengan menggunakan blackbox testing.

Untuk mengakses sistem registrasi online penerimaan siswa baru, dibutuhkan akun yang terdiri dari email dan password. Kemudian setelah memiliki akun yang terdaftar, pendaftar bisa mengakses dan melakukan aktivitas pendaftaran sesuai dengan ketentuan yang berlaku. Berikut adalah beberapa tampilan halaman sistem registrasi online penerimaan siswa baru.

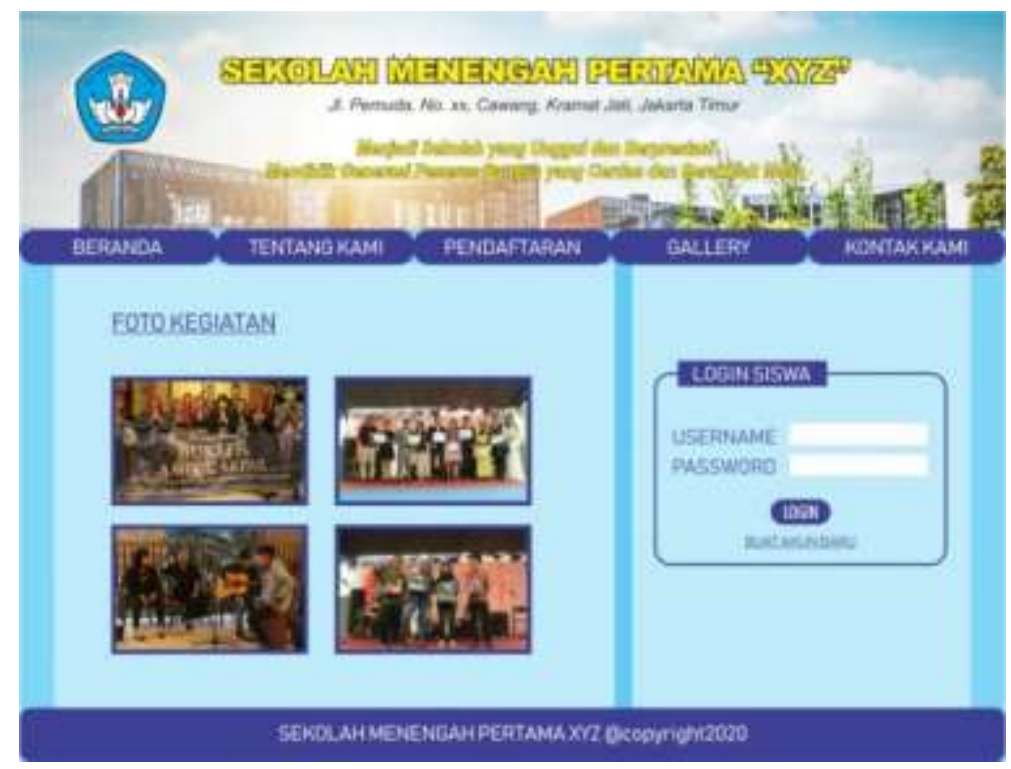

Gambar 5. Halaman Beranda

Pada gambar 5. Merupakan tampilan halaman beranda dari sistem registrasi online penerimaan siswa baru sebelum melakukan pendaftaran akun baru.

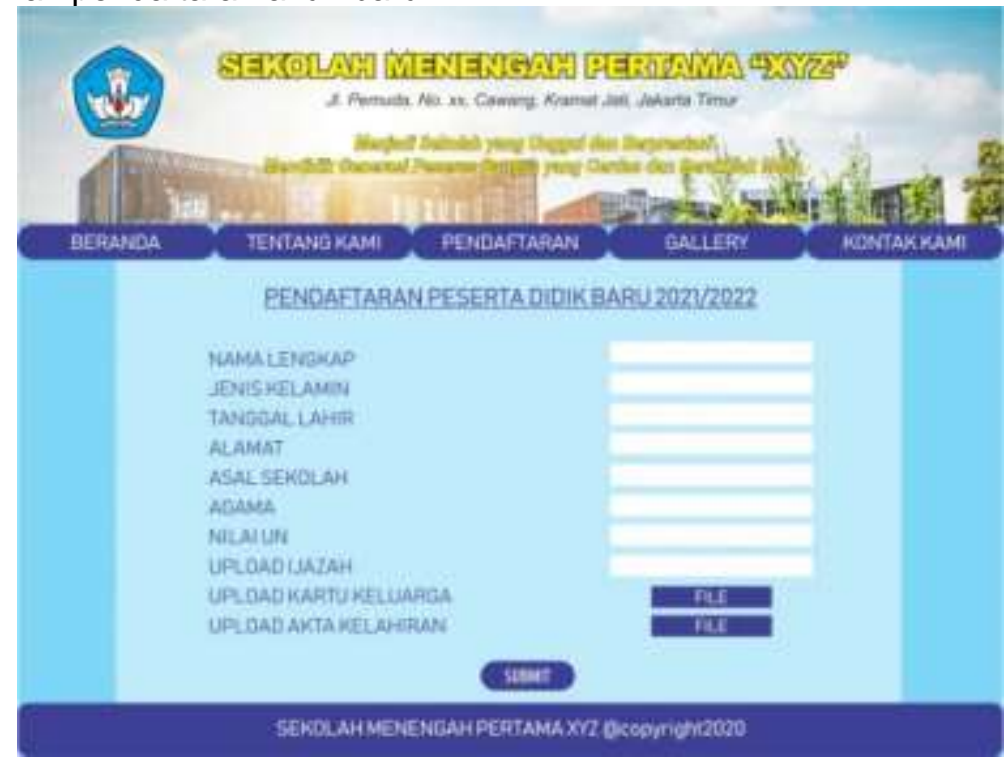

Gambar 6. Halaman pendaftaran

Pada gambar 6. Merupakan tampilan form pendaftaran untuk melakukan input data diri calon siswa. 


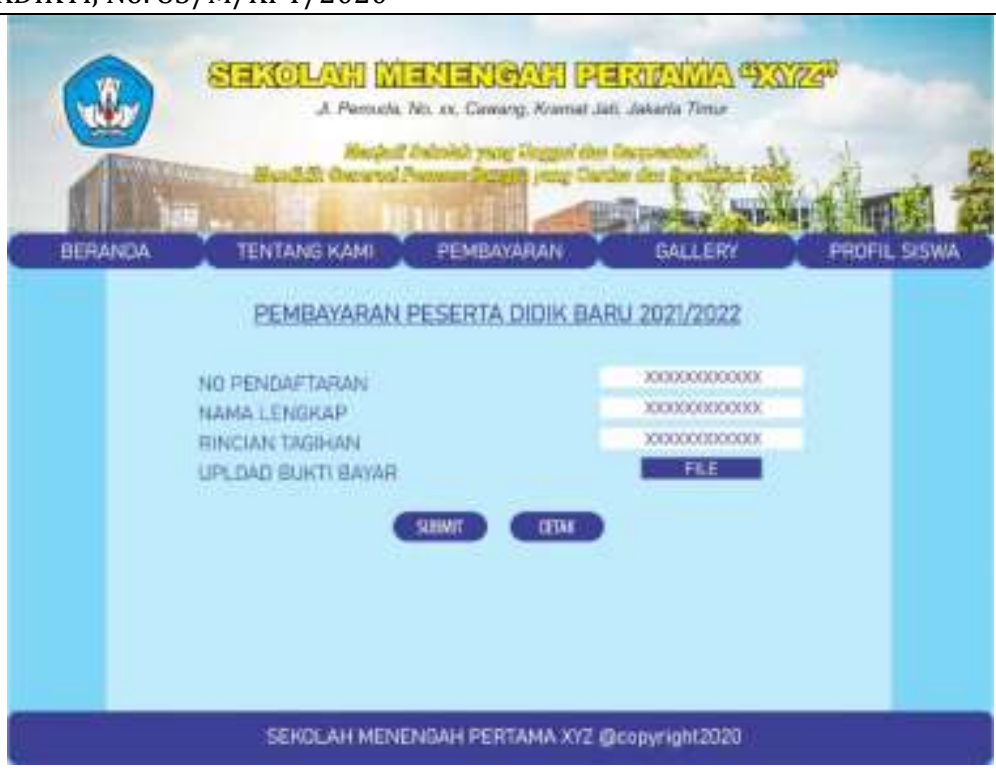

Gambar 7. Halaman pembayaran

Pada gambar 7. Merupakan tampilan rincian pembayaran yang harus dibayarkan oleh calon siswa yang diterima. Di halaman tersebut tersedia file upload bukti bayar. Setelah siswa upload bukti bayar, siswa dapat mencetak bukti pembayaran.

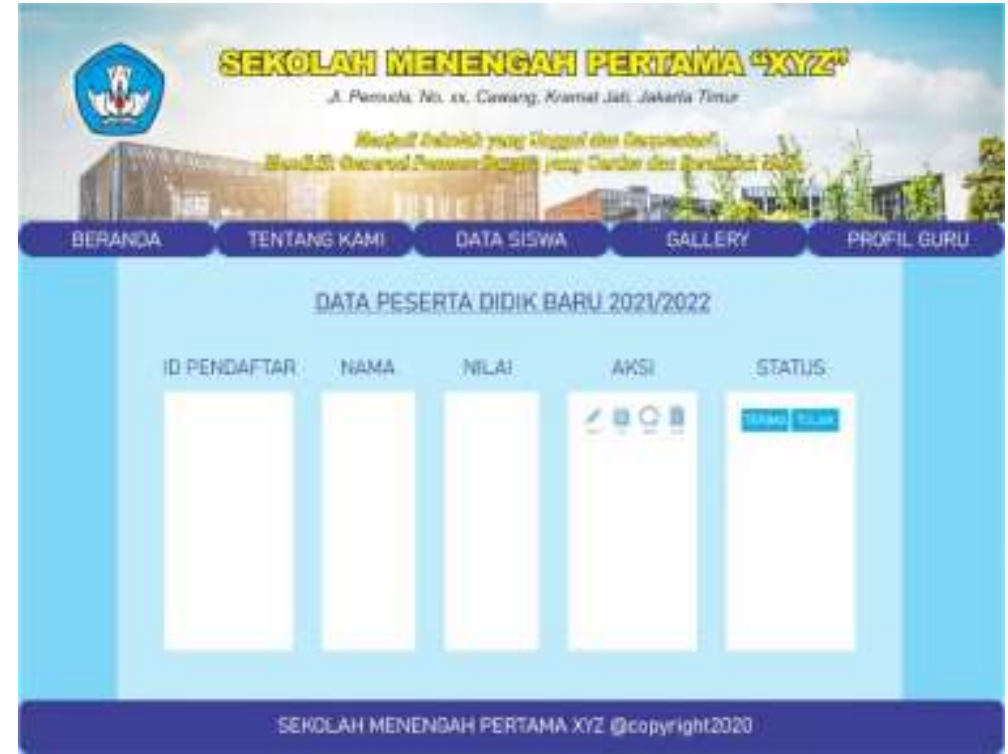

Gambar 8. Halaman guru

Pada gambar 8. Merupakan halaman untuk guru. Halaman ini akan muncul setelah guru melakukan login dengan username dan password yang valid. Guru dapat melihat data pendaftar, dapat mengedit data siswa yang mendaftar dan dapat memfilter calon siswa yang diterima atau ditolak. 


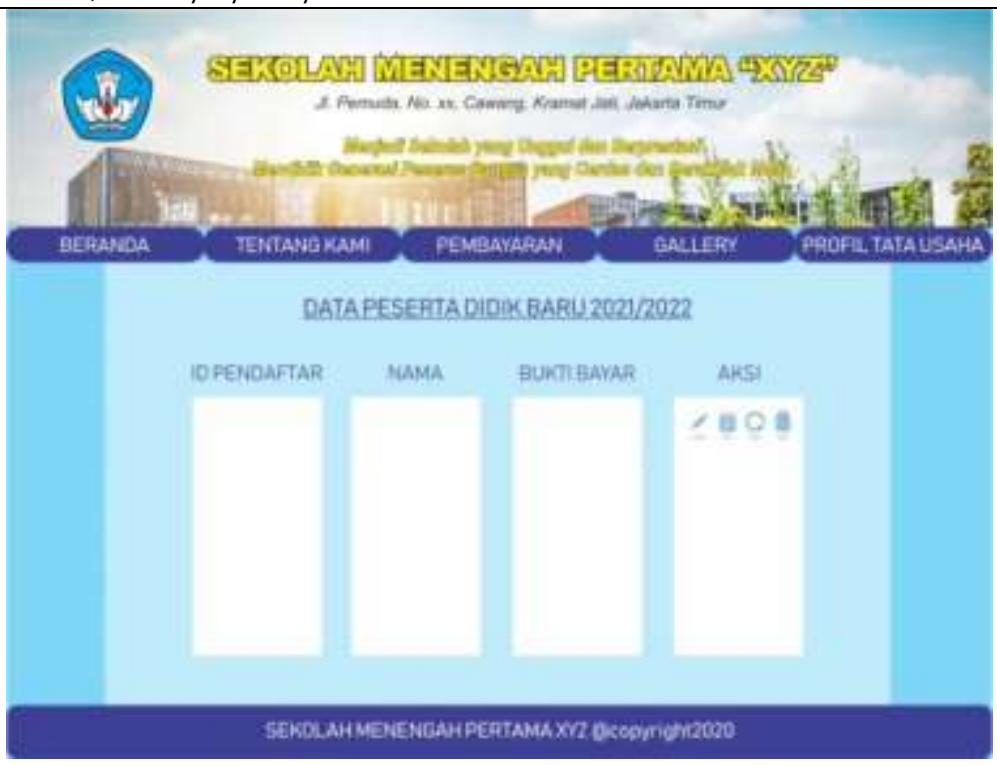

Gambar 9. Halaman tata usaha

Pada gambar 9. Di atas merupakan halaman tata usaha yang mana dapat melihat data calon siswa yang sudah melakukan upload bukti bayar. Halaman ini akan muncul setelah Tata Usaha melakukan login dengan username dan password yang valid. Pihak Tata Usaha dapat melakukan edit data pembayaran.

\subsection{Testing and Turnover}

Pada tahap ini dilakukan pengujian sistem menggunakan metode blackbox testing. Pengujian dilakukan terhadap hal-hal yang fungsional dari sebuah sistem. Perangkat lunak akan dipandang seperti sebuah "kotak hitam" yang tidak begitu penting isinya, tapi hanya dikenai proses testing di bagian luar .

Tabel 1. Hasil Test sistem dengan metode Blackbox testing

\begin{tabular}{|c|c|c|}
\hline Skenario Pengujian & Hasil yang diharapkan & Hasil Pengujian \\
\hline $\begin{array}{l}\text { Menu form pendaftaran } \\
\text { Salah satu data dikosongkan klik } \\
\text { tombol simpan }\end{array}$ & $\begin{array}{l}\text { Sistem akan menolak untuk } \\
\text { simpan }\end{array}$ & Valid \\
\hline $\begin{array}{l}\text { Email: (Salah) } \\
\text { Password: (Benar) begitu juga } \\
\text { sebaliknya kemudian klik tombol } \\
\text { login }\end{array}$ & $\begin{array}{l}\text { Sistem akan menolak akses } \\
\text { login dan menampilkan } \\
\text { "Gagal Masuk" }\end{array}$ & Valid \\
\hline $\begin{array}{l}\text { Email: (Kosong) } \\
\text { Password: (diisi) begitu juga } \\
\text { sebaliknya } \\
\text { kemudian, klik tombol login }\end{array}$ & $\begin{array}{l}\text { Sistem akan menolak akses } \\
\text { login dan menampilkan } \\
\text { "please fill out this Field" }\end{array}$ & Valid \\
\hline $\begin{array}{l}\text { Menu rincian pembayaran } \\
\text { Upload bukti : (kosong) }\end{array}$ & $\begin{array}{l}\text { Sistem akan menolak untuk } \\
\text { simpan }\end{array}$ & Valid \\
\hline
\end{tabular}

\section{KESIMPULAN}

Berdasarkan sistem registrasi online penerimaan siswa baru yang telah dibangun dengan menggunakan metode RAD, dapat diambil kesimpulan bahwa dengan adanya sistem tersebut dapat mempermudah proses penerimaan siswa baru di masa pandemi Covid-19. Sistem mampu meminimalisir interaksi secara langsung antara calon siswa dan pihak sekolah sehingga mengurangi penyebaran virus Covid-19. Selain itu, sistem juga memudahkan pihak guru dan pihak tata usaha dalam mengelola data siswa dan data administrasi pendaftaran secara lebih efektif dan efisien sehingga meminimalisir resiko terjadinya redudansi data. Pengujian terhadap fungsionalitas sistem registrasi online penerimaan siswa baru dilakukan dengan metode black-box-testing 
Indonesian Journal on Software Engineering (IJSE)

Vol. 7, No. 1, Juni 2021, hlm. 69-77

p-ISSN: 2461-0690

Akreditasi KEMENRISTEKDIKTI, No. 85/M/KPT/2020

e-ISSN: 2714-9935

\section{REFERENSI}

Bolung, M., \& Tampangela, H. R. K. (2017). Analisa Penggunaan Metodologi Pengembangan Perangkat Lunak. Jurnal ELTIKOM, 1(1), 1-10. https://doi.org/10.31961/eltikom.v1i1.1

Citra, D., Hadi, I., \& Sarjana. (2020). Platformweb Sebagai Penampil Data Monitoring Kotak Sampah Berbasis lot. JIRE (Jurnal Informatika \& Rekayasa Elektronika), 3(1).

Hasugian, H., \& Salma, V. (2017). Pemodelan Sistem Informasi Pelayanan Jasa Repair Modem Dan Penjualan Modul Vsat Pada Pt. Paradise Communications Berbasis Object Oriented Menggunakan Unified Modeling Language. Seminar Nasional Teknologi Informasi Dan Multimedia 2017, 49-55 ISSN : 2302-3805.

Hidayat, T., \& Muttaqin, M. (2018). Pengujian Sistem Informasi Pendaftaran dan Pembayaran Wisuda Online menggunakan Black Box Testing dengan Metode Equivalence Partitioning dan Boundary Value Analysis. Jurnal Teknik Informatika UNIS JUTIS, 6(1), 2252-5351. www.ccssenet.org/cis

Hidayat, T., Muttaqin, M., \& Djamaludin, D. (2020). Sistem Informasi Penerimaan Peserta Didik Baru Online Berbasis Website di Yayasan Pendidikan Arya Jaya Sentika. Komputika : Jurnal Sistem Komputer, 9(1), 7-14. https://doi.org/10.34010/komputika.v9i1.2750

Khasanah, N., \& Komarudin, R. (2020). Implementasi Sistem Seleksi Pendaftaran Kelas Inkubasi di Yayasan Sedekah IImu Berbasis Website. 6(1), 126-132.

Lestari, N., Daulay, N. K., \& Armanto. (2020). Simulasi Monitoring Pengatur Kecepatan Kipas Angin Menggunakan Sistem Fuzzy Berbasis Web. 3(1).

Maria, S., \& Sakdiah, N. (2019). Rancang Bangun Sistem Informasi Seleksi Penerimaan Siswa Baru Di SMA Negeri 2 Plus Panyabungan Berbasis Web. Jurnal Intra-Tech, 3(1), 16-27.

Oky, I., \& Listianto, G. B. A. (2018). Metode Rapid Application Development (RAD) pada Perancangan Website Inventory PT. SARANA ABADI MAKMUR BERSAMA (S.A.M.B) JAKARTA. Evolusi : Jurnal Sains Dan Manajemen, 6(2), 12-18. https://doi.org/10.31294/evolusi.v6i2.4414

Prabowo, W. S., \& Agustina, C. (2017). Perancangan Sistem Informasi Pengolahan Nilai Rapor Berbasis Web Pada SMK Negeri 1 Purworejo. Jurnal Khatulistiwa Informatika, 1(1), 48-57. http://ejournal.bsi.ac.id/ejurnal/index.php/khatulistiwa/article/view/2288

[Putra, M. Y., \& Shadiq, J. (2020). Sistem Informasi Penerimaan Siswa Baru pada SMK Bekasi Berbasis Website. BINA INSANI ICT JOURNAL, 7(1), 43-52.

Sari, A. M. (2017). Aplikasi Situs Web Penjualan Hijab Online. Paradigma, 19(2), 113-117. http://ejournal.bsi.ac.id/jurnal/index.php/paradigma/article/view/2290/1616

Sarwindah. (2018a). Sistem Pendaftaran Siswa Baru Pada SMP N 1 Kelapa Berbasis Web. Jurnal Sisfokom (Sistem Informasi Dan Komputer), 7(2), 110-115.

Sarwindah, S. (2018b). Sistem Pendaftaran Siswa Baru Pada SMP N 1 Kelapa Berbasis Web Menggunakan Model UML. Jurnal Sisfokom (Sistem Informasi Dan Komputer), 7(2), 110. https://doi.org/10.32736/sisfokom.v7i2.573

Suhartini, S., Sadali, M., \& Kuspandi Putra, Y. (2020). Sistem Informasi Berbasis Web Sma Al- Mukhtariyah Mamben Lauk Berbasis Php Dan Mysql Dengan Framework Codeigniter. Infotek : Jurnal Informatika Dan Teknologi, 3(1), 79-83. https://doi.org/10.29408/jit.v3i1.1793 